\title{
WPS3620
}

\section{Leadership and the Independent Regulator}

\author{
Mark A. Jamison \\ Public Utility Research Center \\ University of Florida
}

\begin{abstract}
Being a utility regulator has perils because the independence of the regulator necessarily removes power from politicians, operators, and others. Furthermore, regulators are sometimes scapegoats for unpopular policies and unavoidably become involved in shaping the policies that they are supposed to implement. As a result of such frictions, regulators are sometimes removed from office or marginalized in some way. How can regulators not only survive in such an environment, but also thrive? This paper describes a leadership concept called adaptive leadership that regulators can use to help their countries adapt to new policies and changing situations, while allowing the regulator to stay in the game. The first leadership skill discussed is the ability to get on the balcony to see what is really going on with operators, politicians, consumers, and others. Once this perspective is obtained, then the regulator can engage stakeholders in an adaptive process in which people make necessary changes to traditions and expectations, while hanging on to the things that are truly important. Regulators can do this by bringing attention to problems that people want to ignore because they involve difficult trade-offs, providing certainty and stability when tensions become too high for work to be done, and keeping attention focused on the work and the issues.
\end{abstract}

World Bank Policy Research Working Paper 3620, June 2005

The Policy Research Working Paper Series disseminates the findings of work in progress to encourage the exchange of ideas about development issues. An objective of the series is to get the findings out quickly, even if the presentations are less than fully polished. The papers carry the names of the authors and should be cited accordingly. The findings, interpretations, and conclusions expressed in this paper are entirely those of the authors. They do not necessarily represent the view of the World Bank, its Executive Directors, or the countries they represent. Policy Research Working Papers are available online at http://econ.worldbank.org.

Contact details

205 Matherly Hall

PO Box 117142

University of Florida

Gainesville, Florida 326711-7142

USA

Tel: +1.352 .392 .6148$

Fax: +1.352.392.7796

Email: jamisoma@ufl.edu 


\title{
Leadership and the Independent Regulator
}

\author{
Mark A. Jamison ${ }^{1}$ \\ Public Utility Research Center \\ University of Florida
}

\section{Introduction}

When the Governor of Iowa appointed Dennis Nagel to be Chairperson of the Iowa Utilities Board, the only thing the Governor requested was that Nagel not do anything that would cost the Governor the next election. The Governor didn't mention protecting consumers, protecting shareholders, or even obeying the law - he only asked that Nagel not cost him the next election.

It is likely that politicians appoint independent utility regulators ${ }^{2}$ with an expectation, even if unspoken, that the regulators will provide a certain amount of stability. Controversies over utility regulation can cause politicians to lose elections, particularly in view of the well-accepted proposition that regulation should protect consumers (Kahn, 1988). John Carlin was able to defeat incumbent Governor Robert Bennett to become Governor of Kansas in 1978 in part because Carlin convinced voters that Governor Bennett was not tough enough on utility companies. Regulatory controversies can cause unrest in other ways. Ugandans took to the streets of Kampala in June 2003 to protest a price increase allowed by the electricity regulator. News writers in Trinidad and Tobago accused the Regulated Industries Commission (RIC) of putting the profits of the incumbent telephone company ahead of consumer interests in April 2004 when the RIC closed down unlicensed telecommunications providers (Trinidad \& Tobago Express, 2004).

What happens when a regulator whose function is, in part, to keep things calm lands in the middle of controversy? The regulator finds him- or herself in peril. In

\footnotetext{
${ }^{1}$ Director, Public Utility Research Center, University of Florida, Gainesville, Florida, USA, http://www.purc.org; and Associate, Cambridge Leadership Associates, http://www.cambridge-leadership.com/. I would like to thank Sanford Berg, Lynne Holt, Toni Sotkiewicz, Paul Noumba Um, Janice Hauge, Patricia Mason, and an anonymous referee for their helpful comments. Any errors are my own. An earlier version of this paper was titled "Survival Guide for the Independent Regulator.”

${ }^{2}$ A regulator is generally considered independent when he or she has arm's-length relationships with industry, consumers, private interests, and politicians. This paper focuses on independent regulators, but the leadership concepts described are general and could apply to many roles that require exercising leadership.
} 
Zambia, a regulator was fired for allowing a politically unpopular price increase even though the increase was required by law. At times in the United States, regulators who have been viewed as too outspoken or too politically active by politicians have lost their jobs. In one state a review committee decided an outspoken regulator was unqualified for her job when she came up for reappointment. In another state the legislature removed the sitting regulators from office by abolishing the existing agency and creating a new one.

Being an independent regulator or taking steps to become one is perilous work for at least three reasons. In the first instance, there will be some people who have to give up things they value with the development and exercise of regulatory independence (Butler, 2003). A politician stands to lose political power, an operator may lose opportunities to apply political pressure, and some consumers may lose the means to gain favorable treatment. Those who experience a loss because of regulatory independence may attack what they believe to be the source of the problem, the regulator. The second reason independence has risks is that in developing and refining independence, the regulator becomes a player, which compromises the very independence he or she is trying create or practice. Lastly, regulation has perils because the regulator plays a central role in a complex system that develops and implements policies, but the regulator has only limited authority over this system (Nadel, 1990-91). As a result, politicians may use the regulator as a scapegoat for ineffective or unpopular policies, or for policies that are difficult to explain to the public.

This paper explains why the work of the regulator has perils and describes some ways regulators can survive and thrive. I use as my unit of study a person serving in the role of independent regulator for two reasons. First, leadership is ultimately a personal act in that it is the individual who discerns the situation and engages the work. My second reason for focusing on the individual is that the perils of regulation are often personal. In the situation cited regarding a legislature that rewrote regulatory statutes, the purpose was to remove individual regulators from office. ${ }^{3}$ Furthermore, I focus my study on the independent regulator rather than regulators who lack independence because, as I

\footnotetext{
${ }^{3}$ This illustrates a linkage between the individual and the institution. The acts of individuals can permanently affect the institution, as in this example. Furthermore, the formal and informal rules of the institution can constrain the individual or put her in peril. For example, individual regulators have only limited options for defending themselves from attacks from persons within the legislative body if the regulatory agency is a creation of the legislature.
} 
explain below, independence creates unique hazards. However, many of the lessons in this paper can be applied to persons working in regulatory agencies that are not considered independent.

The remainder of this paper is organized as follows. I begin by explaining what I mean by independence and summarize the perils of regulatory work. I then describe the regulator's leadership role and some tools that regulators can use to succeed. I conclude by describing how regulators can develop the necessary leadership skills.

\section{Independence}

Regulatory independence generally means the regulator and the regulatory institution have arm's-length relationships with the operator(s), consumers, private interests, and political authorities (W. Smith, 1997). One way countries ensure an arm'slength relationship between the regulator and the operator is to prohibit the regulator from having a stake in the operator's financial success. For example, when I was head of the Research Section for the Iowa Utilities Board (IUB), I could not own stock in the companies I regulated. The Chairperson of the IUB at the time recused himself from several cases involving AT\&T because his former law firm had worked for AT\&T. No one working for the IUB could receive as much as a cup of coffee from someone who worked for an operator that the agency regulated.

Laws also promote independence for the regulator by imposing organizational autonomy for the institution and an arm's-length relationship with the political authorities. This is often accomplished through earmarked funding for the institution, fixed and staggered terms of appointment for regulators, restrictions on removal of regulators from office without cause, statutory or constitutional authority for the institution, and court reviews of regulatory decisions rather than ministry reviews (W. Smith, 1997). For example when the Uganda Communications Commission was established, its decisions were reviewable only by a special court tribunal, not by a ministry. Political independence also means limits on ex parte communications with politicians. Soon after being appointed to the California Public Utilities Commission, one regulator began receiving telephone calls from politicians telling him how he should decide upcoming issues. His approach was to tell the callers that he could not act on their 
request unless it was part of the public record and would they please put their request in writing so that he could consider it and make it public. No letters came and the telephone calls eventually stopped.

Independence from short-term political influences is important because such interests lead to opportunistic behavior (Wells and Gleason, 1995). Opportunism in utility policy is evident when, for example, policymakers ex post change the rules affecting the operators' ability to retain profits from investments made before the rule change. In illustration, regulators in the U.K. resisted pressures from the Labour Party to claw back utility profits after privatization because this would have been considered a breaking of the regulatory compact with the operators. However, once the Labour Party took control of the government, utility profits became a legislative issue rather than a regulatory issue, and the country adopted a windfall tax to capture past profits. ${ }^{4}$ Some investors pulled out of the country as a result of this tax (Institute for Fiscal Studies, 2000). Because the threat of political opportunism discourages long-term investments, many countries make their regulatory agencies independent of political influence so that the agency provides a stable and credible legal environment (Goldberg, 1976; Levy and Spiller, 1996; Spiller and Savedoff, 1999).

Independence does not mean that the regulator answers to no one. An independent regulator is governed by laws, political realities, public sentiments, budgets, license provisions, and such. Independence is not absolute because trade-offs exist between certain features of regulation, such as that between independence and accountability, between certainty and flexibility, and between long-term goals and shortterm viability. This lack of absolute independence is generally considered desirable because it ensures that the regulator is not simply following a personal agenda.

\section{Perils in Regulation}

As indicated, developing and implementing independence can be perilous for the regulator because finding the optimal mix of independence, accountability, flexibility, and the like is difficult. Also, making the necessary trade-offs is painful for some

\footnotetext{
${ }^{4}$ Labour came into power in part because it argued that utility profits had been excessive under the Conservative Party.
} 
because changes in the mix cause some stakeholders to lose things they value, such as political power, secrecy, and flexibility.

Stakeholders at risk for losing things they value are tempted to strike back, perhaps by trying to marginalize the person or agency that they perceive as the threat. This is what happened in Panama when the agency tried to enforce service quality rules on an incumbent service provider. The operator renegotiated its license with the ministry in a way that removed the agency's leverage for enforcing the service quality standards. In the United States, an incumbent telephone operator in one state became so concerned about what it viewed as activist tendencies of a commissioner that it hired a private detective to investigate the commissioner. The commissioner found out and sued the company, counter suits followed, and the situation escalated to the point that the commissioner was recused from any decisions relating to the operator.

Independence is also problematic because the regulator becomes a player while developing and shaping independence, which compromises the very independence the regulator is practicing. Unfortunately, the regulator cannot help but be a player, whether formally or informally. When asked to play a formal policy role, the regulator advises ministers, legislators, and the like on licenses and other policy matters. For example, U.K. regulators provided input on a government review of regulation in that country and commissioners from the U.S. Federal Communications Commission (FCC) were asked to testify before Congress during the writing of the country's Telecommunications Act of 1996.

The regulator always plays an informal policy-making role. For example, in Trinidad and Tobago, the RIC had to choose between staying on the sidelines and acting to fill the regulatory void that occurred when the government delayed establishing the Telecommunications Authority of Trinidad and Tobago (TATT). Both action and inaction had implications for how the government, the TATT, and other stakeholders would view the RIC. The former director of Jamaica's Office of Utilities Regulation (OUR), Winston Hay, made a decision to talk with the press about the Jamaican government's failure to authorize the OUR's budget (Jamaica Gleaner, 2000). His decision had implications for how the ministry, press, and public viewed the OUR. However, a decision to remain silent would also have had implications. 
The work of independence is particularly complex in small economies because the small sizes of these economies make true arm's-length relationships difficult to establish and maintain. As a former regulator from a small economy put it, "Everyone knows everyone and has their fingers in everything." In small economies, the development of independence involves changing informal rules and relationships that are well-known and valued even if they are incompatible with necessary improvements in utility markets (Tenenbaum, 1996; Buscaglia and Ratliff, 2000).

The regulator's role as scapegoat adds to the regulator's perils. One regulator in an Asian country encouraged the country's communications minister to blame him, the regulator, for a price increase rather than intervene in the pricing decision. This scapegoating preserved the pricing policy, but it diminished the public's view of the legitimacy of the regulator. When I served on staffs of regulatory commissions in the United States, it was common for operators to notify customers of price increases with words to the effect that the commission had ordered the operator to increase prices even though the commission had only allowed the price increase. In another situation a regulator reversed his earlier decision on a pricing issue because he believed that he would be unable to counter an operator's negative comments in the press. The regulator had initially refused to allow costs for a non-regulated service to be covered by prices for regulated services. However, the public believed these non-regulated services would stimulate the local economy, and the company told the press that the regulator's initial decision would harm economic development.

\section{Authority versus Leadership}

A regulator's leadership role is different from the regulator's authority role. See Table 1. People expect authority figures to provide answers. Witness, for example, the recent U.S. presidential election where both major candidates said they knew how to achieve tranquility and economic growth. Arguably, they were responding to what people wanted to hear. In contrast to authority, leadership is about "mobilizing people to tackle tough problems” (Heifetz, 1994, p. 15). Leadership raises questions and forces people to face difficult problems whose solutions require a rethinking of valued traditions 
and closely held beliefs. Even though a single act by a regulator may involve both leadership and authority, the leadership role and the authority role are distinct.

Table 1. Authority versus Leadership ${ }^{5}$

\begin{tabular}{|l|l|}
\hline \multicolumn{1}{|c|}{ Authority } & \multicolumn{1}{c|}{ Leadership } \\
\hline $\begin{array}{l}\text { Provides solutions by applying established } \\
\text { instruments from political science, management, } \\
\text { economics and finance, law, and engineering. }\end{array}$ & $\begin{array}{l}\text { Identifies challenges by questioning how } \\
\text { problems should be defined and pointing out why } \\
\text { technical solutions cannot solve adaptive } \\
\text { problems. }\end{array}$ \\
\hline $\begin{array}{l}\text { Protects people and the system from external } \\
\text { threats. }\end{array}$ & $\begin{array}{l}\text { Discloses threats by calling attention to the } \\
\text { fundamental changes in external forces that } \\
\text { threaten the status quo and defy traditional } \\
\text { solutions. }\end{array}$ \\
\hline $\begin{array}{l}\text { Restores order so that work can continue when } \\
\text { internal or external forces disrupt the normal } \\
\text { performance of work. }\end{array}$ & $\begin{array}{l}\text { Exposes real conflicts or facilitates their } \\
\text { emergence so that those involved face and work } \\
\text { through tough choices. }\end{array}$ \\
\hline $\begin{array}{l}\text { Maintains norms so that people can work by } \\
\text { following established rules and procedures, and } \\
\text { not waste time "reinventing the wheel." }\end{array}$ & $\begin{array}{l}\text { Challenges norms to ensure that "solutions" are } \\
\text { not adopted before the new environment is fully } \\
\text { understood, the real conflicts are resolved, and key } \\
\text { trade-offs are made. }\end{array}$ \\
\hline
\end{tabular}

Let me illustrate the difference between leadership and authority with a story from my experience at Sprint, where I worked from 1993 to 1996. The passage of the U.S. Telecommunications Act of 1996 presented a dilemma for Sprint. The Act pitted long distance companies against traditional local telephone companies, and Sprint was in both lines of business. Up until that time, Sprint had played both sides of the street in regulatory debates and sometimes held contradictory policy positions because it was effectively two companies - a long distance company and a local telephone company and the corporate executives had no policy as to which line of business mattered most to the company. When it came to regulatory policy, Sprint was a house divided.

I worked as a policy manager for the long distance side of the company. My colleagues and I thought the Act would finally force the corporate executives to announce Sprint's business direction. We were wrong. This was a problem for my colleagues and me because regulators were asking us for Sprint's positions on implementing the Act and we had nothing to say. I asked a colleague what I should do and she advised me, "Mark,

\footnotetext{
${ }^{5}$ Adapted from Heifetz (1994, p. 127).
} 
just act like you are in charge and see what happens.” To make a long story short, that is what I did and it worked. I recruited a team that identified policy questions that Sprint needed to answer, asked for additional volunteers to write draft corporate positions, and announced deadlines. The executives noticed and assigned the chief operating officer and the corporate general counsel to review our drafts and decide any remaining policy conflicts. It all worked. I had no authority to do this work, but by defining the work and asking people to get involved, I helped bring about a positive change in how Sprint defined its corporate identity.

A regulator may also need to exercise leadership to create legitimacy for doing the work for which he or she has formal authority. This was the situation that Rohan Samarajiva faced when he became Sri Lanka's Director General, Telecommunications Regulatory Commission, in 1998. Sri Lanka had recently adopted telecommunications reforms, and the reform agreement included a provision for significant domestic price increases. Samarajiva was required by law to allow the price increases, but he knew there would be a large public outcry. He prepared the public, the media, and the ministry for the increase by forcing the operator to completely document the reasons for the increase. He provided a detailed explanation of the price increase during a press conference, the first the agency had ever held, and hosted consumer call-in programs on broadcast radio. In addition, he required the operator to offer a low-use tariff. These steps established arm's-length relationships between the regulator and some of the stakeholders, gave the stakeholders roles in the process, recognized customers' pain, and emphasized transparency (Samarajiva, 2001).

How does the regulator exercise leadership and not only survive, but thrive? Entire books are written on this topic (see, for example, Heifetz, 1994; Heifetz and Linsky, 2002; Laurie, 2000), but I will summarize some of the main techniques that I have witnessed; namely, getting on the balcony, identifying the adaptive work, creating a holding environment, and modeling best practice.

\section{Get on the Balcony}

Getting on the balcony is a metaphor for seeing what is really going on with yourself and others. On a dance floor, you can see only yourself and the people 
immediately around you. That gives you one perspective on what is happening. But if you leave the dance floor and get up on the balcony, you can see everything that is going on; i.e., who is dancing and who is not, how the music affects different dancers, where dancers are on the floor, etc. (Heifetz and Linsky, 2002, pp. 51-74)

Getting on the balcony incorporates the emotional intelligence skills of social awareness, self-awareness, and self-management (Goleman et al., 2002, pp. 39-50). Social awareness involves sensing others' emotions, perspectives and motives and the political and personal relationships among the persons relevant to the situation. By stepping back from the fray and asking questions such as "Who cares about the actions I am taking?” “What seems to happening beyond my vision?” "Why are some people engaged and why are others not engaged?" and "What seems to energize particular people and what seems to lead to resistance?” can help the regulator understand what is happening with others. Self-awareness involves reading one's own feelings and understanding personal strengths and weaknesses. One former regulator said she used to employ what she called the "smell test," which meant that she would seriously question proposals that didn't feel right even if she could not pinpoint the problem. Selfmanagement includes controlling one’s own responses, displaying integrity, adapting to situations, and acting on opportunities. Exercising self-awareness and self-management can be some of the more difficult things to do in a leadership role, but they are fundamental to getting on the balcony (Heifetz and Linsky, 2002; Laurie, 2000; Goleman, 1994; Cooper and Sawaf, 1997).

I failed to get on the balcony when working for the regulatory agency in Iowa. The IUB had a long tradition of using fully distributed cost studies in the 1980s, but increasing competition at the fringes of the local telephone monopoly and rapid changes in technology made this policy problematic. Because cost analysis was one of my areas of expertise, the Iowa commissioners asked me to direct a process to establish new costing rules. I attacked this as a technical challenge and wrote a staff proposal that correctly applied the most current economic theories. I then invited industry economists to join me in a series of workshops to refine the proposal.

The workshops were a disaster. Economists from the industry derailed the first two workshops by arguing about pricing issues rather than costing rules. I was worried 
when it came time for the third workshop, but the people who derailed the first two didn't attend and I was able to get the industry representatives to agree with me on a set of principles that could be the foundation for a new IUB policy. However, when I presented these principles to my commissioners, they flatly rejected them. I felt I had nowhere to turn and let the process stop, a personal loss for me because I had prided myself on being an expert in cost analysis. Although I understood the economics of the issue, I had failed to get on the balcony to see what was going on in the larger perspective.

From the balcony, I would have seen that the people who derailed the workshops did so because the industry did not want tightly defined costing rules. It wanted flexibility. I would also have seen that my commissioners needed tightly defined costing rules so that the rules could withstand court challenges. It was impossible to satisfy both the commissioners and the industry, but I had adopted a process that I could not complete without consensus. I should also have recognized that I was motivated by the technical challenge of the issue and my ego. If I had gotten on the balcony, I could have developed workshops that defined issues, clarified perspectives, and engaged others in defining the policies to be forwarded to the commissioners. This would have allowed my commissioners to initiate a rulemaking proceeding with a high probability of success.

\section{Identify Adaptive Work}

An important element of being on the balcony is identifying the adaptive work to be done and who has to do it. Adaptive work involves making changes in values, traditions, attitudes, and behaviors that people hold dear (Heifetz and Linsky, 2002, pp. 11-20). It lies at the core of an organization's ability to succeed.

The need for adaptive work arises when fundamental changes in a group's (or an individual's) environment call for a rethinking of basic goals and strategies to thrive or even just survive. Examples of major changes that have affected utility policy include the energy crisis in the 1970s, nuclear accidents at Three Mile Island and Chernobyl, decisions by multilateral institutions such as the World Bank to promote privatization and competition in utilities, and the development of the Internet, but numerous more minor changes exist. According to Laurie (2000, pp. 39-40), a person exercising leadership is able to recognize adaptive work by identifying deeply held beliefs that are inconsistent 
with the future, discovering the new learning and the unlearning that has to take place, and determining what competing values are at stake. Leadership in such situations questions long-held assumptions that may not be viable in the new environment and exposes people to the reality of new situations that must be understood for an effective response (Heifetz, 1994; Heifetz and Linsky, 2002; Laurie, 2000; Pascale et al., 2000; see Table 1).

Patrick Masambu was Managing Director of Uganda Telecomm Limited (UTL), the country's state-owned operator, in the mid-1990s. Seeing that privatization and competition in telecommunications were important for his country and probably inevitable, he understood the need to change his own career path and to help his staff and the labor union see the future. Recognizing that privatization would mean a new management team for the company, he left UTL and became Executive Director and Commissioner of the Uganda Communications Commission (UCC). This was a controversial move that some saw as opportunistic, but it focused attention on the role of the UCC and helped the UTL management and laborers begin adjusting to the new business environment. The UCC has since helped the country adjust to global telecommunications by engaging operators, ministries, its staff, and representatives of nearby countries in an international dialogue that has involved joint training, exchange meetings with neighboring countries, and participation in International Telecommunications Union activities.

Policymakers in four countries - Thailand, the Philippines, Malaysia and Indonesia - engaged their countries in adaptive work in 1997. Each country had undertaken some degree of privatization of its electricity system prior to the 1997 East Asian financial crisis. The crisis brought public pressure on the governments to renegotiate contracts with the private investors. Policymakers faced difficult trade-offs between addressing their citizens' immediate financial distress and keeping commitments to investors, and difficult leadership challenges as they worked to change their own and their citizens' perceptions about the future. The countries engaged in similar processes, which included varying degrees of public protest, statements from politicians, and negotiations with investors, but their outcomes were different. Government institutions in Thailand and the Philippines had more extensive checks and balances than did the 
institutions in Malaysia and Indonesia. These checks and balances protected investors, which meant that investors in Malaysia and Indonesia had to engage in more adaptive work than their counterparts in Thailand and the Philippines (Henisz and Zelner, 2004).

This raises another point with adaptive work, namely, that in any given situation there may be those whose norms and values are consistent with the new realities, which means that they do not need to engage in adaptive work. For example, some advocates for the poor have held that the poor should receive the same level and quality of utility service as those who are wealthier. In some countries this level of service has proven to cost more than could be funded. Furthermore the poor in those countries, when given the choice, preferred lower levels of service that they could afford. This reality conflicted with the values of the advocates of the poor, so they had to adjust their expectations. The poor, in contrast, needed no such adjustments.

\section{Create a Holding Environment}

While getting on the balcony is an important part of the leadership process, it is also important to quickly get back into the fray and orchestrate the process in a way that allows adaptive work to be done (Heifetz and Linsky, 2002, pp. 53, 101-22). This involves both increasing stress when people are refusing to engage in the work that needs to be done and lowering stress when people are feeling overwhelmed. This is called creating a holding environment.

Chairperson Nagel of the IUB created a holding environment for his fellow U.S. state commissioners in 1993 when he helped them realize that the days of monopoly telephone service, with its implicit subsidies and traditional utility regulation paradigm, were coming to an end. He created a unique event - a regulatory summit for state commissioners only - at Keystone, Colorado. Here the commissioners heard from technology visionaries and aggressive corporate executives who planned to take on the telephone monopolies. The uniqueness of the summit and the power of the presentations focused attention and shook the traditional paradigms. The event included discussion groups with handpicked facilitators to involve the commissioners and help them process what they were hearing. After the summit, the commissioners continued to work in task groups to help them focus on manageable tasks while not losing momentum. In part as a 
result of Nagel's work, the state regulators played a leading role in opening U.S. local telephone markets to competition, and Illinois served as a model for the competition rules eventually adopted by the FCC.

A holding environment engages people in emotional and analytical thinking. Emotional thinking motivates people and helps them understand what is truly valuable. Adaptive challenges often threaten people's futures or their views of their own self worth. These threats can lead to feelings of anxiety or anger (Lazarus and Lazarus, 1994), which can motivate people to engage in adaptive work if two conditions are met. First, the threats need to come from the need for adaptive work. For example, policymakers in the Philippines motivated the incumbent telephone operator to improve its service quality and availability by threatening to open the country's telecommunications markets to competition (P. Smith, 1995). This threat challenged the managers' egos and increased the uncertainty about their futures. It also demonstrated the value that the managers placed on their monopoly status. The second condition is that the adaptive work must alleviate the negative emotions. Investigating adaptive challenges and possible solutions engages people in analytical work that decreases anxiety by increasing certainty and that decreases anger by restoring self-confidence if the adaptive work appears to be bringing success. However, if anger and anxiety are too high, they can inhibit analytical thinking, so persons providing leadership may need to find ways to lower stress, perhaps by providing a vision of success. (Heifetz and Linsky, 2002, pp. 120-122)

Making sure that the stress level is neither too high nor too low is one of the more difficult tasks of creating a holding environment. Keeping the stress level from being too high is difficult because tension is a dynamic process. We carry our history with us at all times. As William Faulkner (1951) said, “The past is never over. It's not even past.” U.S. President George W. Bush appears to have not appreciated this insight in his handling of international relations. Shortly after taking office in 2001, he withdrew the United States from the Kyoto Protocol, from the World Court, and from the peace process in Northern Ireland. Whether these policy decisions were right or wrong is not my point; rather, my point is that he took these steps quickly and with minimal dialogue, which caused a sharp rise in tensions between the United States and many other countries. This stress might have been manageable had it not been for the terrorist 
attacks on September 11. President Bush had to respond decisively to these attacks to calm the U.S. citizenry, but he did not find a way to do so without pushing some international relationships beyond the breaking point. In effect, he was in the position of having to balance two holding environments - one domestic and one international - and he could not manage both after September 11.

President Bush's predecessor, Bill Clinton, provides an example of keeping the stress level too low for adaptive work to be done. Former President Clinton followed a well-established pattern for American presidents when he kept U.S. voters happy by ensuring the flow of relatively cheap oil. In doing so he avoided forcing Americans to face the implications of the country's dependence on foreign oil even though this was becoming an increasingly dangerous proposition.

Heifetz and Linsky (2002, p. 111) list several techniques for managing a holding environment. Stress leading to adaptive work can be encouraged by:

1. Drawing attention to the tough questions. U.S. state regulators did this by holding their Keystone summit, which focused attention on changing the traditions threatened by opening local telephone markets to competition.

2. Bringing conflicts to the surface. Some policymakers and regulators help bring conflicts to the surface by providing sunset provisions in their policies. A sunset provision is an expiration date for a policy, which makes it more difficult to delay facing tough issues.

3. Protecting out-of-the-box thinking. The Nigerian Communications Commission facilitates innovative thinking by engaging the public in open forums on a regular basis. Some regulatory agencies and operators fund university research centers in part to ensure that there are outside sources of new ideas and information.

Actions that lower stress when it becomes too great for adaptive work to be done include:

1. Addressing technical aspects of the problem or establishing a problem-solving structure. Both of these actions increase certainty.

2. Taking tough issues off the table. When California experienced its energy crisis, several other jurisdictions delayed work on energy market reform to 
decrease uncertainty. Some stopped work altogether and pursued other means for improving efficiency in their energy sectors.

\section{Modeling Behavior}

Another important tactic for the regulator exercising leadership is to model the behavior that he or she expects from others (Heifetz and Linsky, 2002, pp. 95-98, 108109). Modeling behavior is important for the regulator for two reasons. First, it shows others that the regulator recognizes what others have to give up for change to occur. Second it shows others that the regulator is also willing to pay the price for change.

The Public Utility Research Center's (PURC) previous Director, Sanford Berg, used this approach in helping me establish myself as PURC’s Director in 2004. Berg had been in charge of PURC for approximately 30 years. In a very real sense, the two were mutually defined. When he decided to hand the reins of PURC over to me, he faced a difficult problem: How could he remain involved in PURC's outreach activities that he values so much without undermining my role as director? He accomplished this by modeling the behavior that he expected of others at PURC. He completely stopped making the decisions he used to make. He never refers to how things used to be, never compares his and my management styles except to compliment me, and always accepts every decision made in PURC even when he disagrees. This eased the transition for everyone involved and helped the organization establish new norms.

The need to model behavior takes me back to an earlier point: When the regulator is a player in defining his or her own role, the regulator is doing something that conflicts with the role of an independent regulator. In the extreme, an independent regulator simply implements established laws and policies. We all know that this extreme is unworkable; regulators around the world play policy roles, whether formally or informally. But the more active the regulator is as a player in the policy arena, the more he or she is like a political government official and the more the regulatory agency is like a ministry. This creates a paradox that is hard for the regulator to reconcile.

Ansord Hewitt of the Jamaican OUR faced such a situation in 2004. At a University of West Indies seminar, a student asked him about a telecommunications policy issue in Jamaica. The first thing he said was that the OUR does not set policy, 
then he proceeded to provide the questioner with the information she sought. He affected policy and made the OUR a player in the policy arena by providing information on a

policy issue. However, he modeled the behavior that he expects of his OUR colleagues and his counterparts in the Jamaican government by honoring the difference between the OUR and the ministry.

\section{Developing Leadership Skills}

How might regulators develop the leadership skills they need? One way is to undertake leadership training. Heifetz and Linsky, for example, have developed a teaching technique called case in point that has proven effective in developing leadership skills. Participants engage in workshops that make the class the object of its own study: The class studies its own leadership successes and failures in real time, which provides instant feedback and experience with critical skills such as getting on the balcony and creating a holding environment. This intensive approach to developing leadership skills is especially effective as participants have a regular dialogue with confidants and leadership experts over several months following the initial workshop. A final workshop reinforces the skills that have been learned.

Goleman et al. (2002, pp. 109-112) describe a self-directed approach to enhancing emotional intelligence. Their approach involves working with a confidant who provides candid feedback as the learner establishes goals, assesses his or her own strengths and weaknesses, sets a development plan, and practices the desired skills.

All approaches to leadership development have two things in common. One is that they involve extended practice. The emotional thinking that is key to leadership occurs in the limbic areas of the brain, which can learn only through focused practice, repetition, and feedback. The second thing the approaches to leadership development have in common is that they all involve other people who observe the learner, listen to the learner's perspectives, and ask probing questions that lead to appropriate selfassessment. 


\section{Conclusion}

I have tried to describe how a person can survive and even thrive while exercising leadership as an independent regulator. I described the difference between the regulator's authority and his or her leadership role. I also talked about the need to get on the balcony, identify the adaptive work that needs to be done, create a holding environment, and model behavior.

I would like to close with a saying attributed to Lao-Tzu: "A leader is best when people barely know that he exists. Of a good leader, when his work is done, people say, we did this ourselves." I believe this describes the challenge for the independent regulator, to exercise leadership that focuses attention on the work rather than on the regulator. Otherwise, his or her position as an independent regulator is compromised. 


\section{References}

Buscaglia, Edgardo, and William E. Ratliff. 2000. Law and Economics in Developing Countries, Stanford, CA: Hoover Institution Press.

Butler, Frederick. 2003. "Managing the Regulatory Process Toward Sustainable Development: The View of a Regulator," Presented at the World Forum on Energy Regulation, Rome, Italy.

Cooper, Robert K., and Ayman Sawaf. 1997. Executive EQ: Emotional Intelligence in Leadership and Organizations, New York, NY: The Berkeley Publishing Group.

Faulkner, William. 1951. Requiem for a Nun, New York: Random House, p. 92, as cited in C. Roland Christensen, 1991, "Premises and Practices of Discussion Teaching," in C. Roland Christensen, David A. Garvin, and Ann Sweet, eds. Education for Judgment: The Artistry of Discussion Leadership, Boston, MA: Harvard Business School Press, pp. 1534.

Goldberg, Victor. 1976. "Regulation and Administered Contracts," Bell Journal of Economics, 7(2): 426-452.

Goleman, Daniel. 1994. Emotional Intelligence, New York, NY: Bantam Books.

Richard Boyatzis, and Annie McKee. 2002. Primal Leadership: Realizing the Power of Emotional Intelligence, Boston, MA: Harvard Business School Press.

Heifetz, Ronald A. 1994. Leadership Without Easy Answers, Cambridge, MA: Harvard University Press.

and Marty Linsky. 2002. Leadership on the Line: Staying Alive through the Dangers of Leading, Boston, MA: Harvard Business School Press.

Henisz, Witold, and Bennet Zelner. 2004. "The Political Economy of Private Electricity: Provision in Southeast Asia," Research Center: Reginald H. Jones Center for Management Policy, Strategy and Organization, University of Pennsylvania.

Institute for Fiscal Studies, “Windfall Tax on Privatised Utilities.” November 27, 2000, http://www.ifs.org.uk/corptax/windfall.shtml.

Jamaica Gleaner, "OUR budget still awaiting cabinet approval,” October 24, 2000, http://www.jamaica-gleaner.com/gleaner/20001024/lead/lead3.html.

Kahn, Alfred. 1988. The Economics of Regulation: Principles and Institutions. Cambridge, MA: MIT Press, Reissue Edition, vol. I. 
Laurie, Donald L. 2000. The Real Work of Leaders: A Report from the Front Lines of Management, Cambridge, MA: Perseus Publishing.

Lazarus, Richard S., and Bernice N. Lazarus. 1994. Passion and Reason: Making Sense of Our Emotions, Oxford: Oxford University Press.

Levy, B. and Spiller, P.T., eds. 1996. The Institutional Foundations of Regulatory Commitment: A Comparative Analysis of Telecommunications Regulation, Cambridge: Cambridge University Press.

Nadel, Mark S. 1990-91. "U.S. Communications Policymaking: Who \& Where," Hastings Communications and Entertainment Law Journal (Comm/Ent), 13: 273-323.

Pascale, Richard T., Mark Millemann, and Linda Gioja. 2000. Surfing the Edge of Chaos: The Laws of Nature and the New Laws of Business, New York, NY: Three Rivers Press.

Samarajiva, Rohan. 2001. "Establishing Regulatory Legitimacy.” In Proceedings of the SAFIR workshop on regulatory strategy, S K Sarkar ed., New Delhi: Tata Energy Research Institute on behalf of SAFIR (South Asia Forum for Infrastructure Regulation), pp. 3-16.

Smith, Peter. 1995. "End of the Line for the Local Loop Monopoly?” Public Policy for the Private Sector, Note No. 63, Washington, D.C.: The World Bank.

Smith, Warrick. 1997. “Utility Regulators - The Independence Debate,” Public Policy for the Private Sector, Note No. 127, Washington, D.C.: The World Bank.

Spiller, Pablo and William Savedoff. 1999. "Government Opportunism and the Provision of Water," in Spilled Water: Institutional Commitment in the Provision of Water Services, Washington, D.C.: Inter-American Development Bank, pp. 1-34.

Tenenbaum, Bernard. 1996. "Regulation: What the Prime Minister Needs to Know," The Electricity Journal March 9(2): 28-36.

Trinidad \& Tobago Express, “The RIC - are they really here to protect?”April 28, 2004, http://www.trinidadexpress.com/index.pl/article?id=22959781.

Wells, Louis T. and Eric S. Gleason. 1995. "Is Foreign Infrastructure Investment Still Risky?” Harvard Business Review, September-October 1995, pp. 44 - 55. 